\title{
$\pi$ (Phi)
}

Jurnal Pendidikan Matematika

Volume 4 Nomor 2 Tahun 2020

\section{PEMBELAJARAN MODEL PROBLEM BASE LEARNING (PBL) DALAM UPAYA MENINGKATKAN PRESTASI BELAJAR MATEMATIKA SEKOLAH DASAR}

\author{
Rugayah $^{1}$ \\ SD Negeri 49/IX Sungai Terap Kabuapaten Muaro Jambi ${ }^{1}$ \\ Email : rugayah49@yahoo.com
}

\begin{abstract}
ABSTRAK
Latar belakang penelitian ini adalah rendahnya hasil belajar dan kemampuan berpikir kritis matematika. Tujuan dari penelitian ini yaitu untuk; 1. mengetahui penerapan PBL dan memaparkannya serta untuk meningkatkan hasil belajar dan kemampuan berpikir kritis, 2. mengetahui dan meningkatkan hasil belajar 3. mengetahui dan meningkatkan kemampuan berpikir kritis. Penelitian ini merupakan penelitian tindakan kelas dan dilakukan dengan dua siklus Subjek penelitian adalah siswa kelas III SD Negeri 49/IX Solok sebanyak 28 siswa. Pada penelitian ini menggunakan teknik pengumpulan data meliputi observasi, tes dan kuesioner. Pada penelitian ini Instrumen yang digunakan menggunakan lembar pengamatan, tes soal uraian, dan lembar kuesioner. Analisis data menggunakan statistika deskriptif. Pembelajaran PBL pada penelitian ini melalui beberapa langkah yang meliputi: a. orientasi siswa pada masalah, b. mengorganisasikan siswa untuk belajar c. membantu penelitian mandiri dan kelompok, d. mengembangkan dan menyajikan hasil karya, e. Dapat meningkatkan hasil belajar dan kemampuan berpikir kritis, menganalisis dan mengevaluasi proses pemecahan masalah. Hasil penelitian dapat disimpulkan bahwa upaya meningkatkan hasil belajar dan kemampuan berpikir kritis materi perkalian dan pembagian kelas III A SDN 208/IX Sumber Jaya Tahun Pelajaran 2019/2020 ditempuh dengan menggunakan pembelajaran inovatif Problem Based Learning dapat meningkatkan hasil belajar siswa pada materi perkalian dan pembagian, hal ini ditunjukkan dari hasil belajar siswa sebelumnya pada kondisi awal sebesar 71,92 meningkat pada siklus I sebesar 77,89 dan pada siklus II meningkat lagi sebesar 90,82. Sedangkan pencapaian KKM yang diperoleh siswa mengalami peningkatan dari kondisi awal sebesar 62,28\%, meningkat pada siklus I sebesar 85,18\% dengan KKM 75 dan pada siklus II menjadi 82,14\% dengan KKM 80. Walaupun persentase peningkatan ketercapaian KKM mengalami penurunan pada siklus II, tetapi peneliti meningkatkan target dan nilai KKM disiklus II. Melalui pembelajaran inovatif Problem Based Learning dapat meningkatkan kemampuan berpikir kritis siswa pada materi perkalian dan pembagian kelas III SDN 208/IX Sumber Jaya Tahun Pelajaran 2019/2020. Perolehan nilai siswa dapat dilihat dari nilai kemampuan berpikir kritis kondisi awal 50,35 dengan kriteria sangat tidak kritis meningkat pada kondisi akhir menjadi 71,62 dengan kriteria cukup kritis.
\end{abstract}

Kata kunci:

berpikir kritis; hasil belajar; problem base learning; siswa

\begin{abstract}
The background of this research is the low learning outcomes and the ability to think critically in mathematics. The purpose of this research is to; 1. knowing the application of PBL and describing it and to improve learning outcomes and critical thinking skills, 2. knowing and improving learning outcomes 3. knowing and improving critical thinking skills. This research is a classroom action research and was conducted in two cycles. The research subjects were 28 students of grade III SD Negeri 49 / IX Solok. In this study using techniques. Data collection includes observation, tests and questionnaires. In this study, the instruments used were observation sheets, test questions description, and questionnaire sheets. Data analysis used descriptive statistics. PBL learning in this study takes several steps which include: $a$. student orientation on problems, $b$. organize students to learn c. assisting independent and group research, d. develop and present the work, $e$. Can improve learning outcomes and critical thinking skills, analyze and evaluate the problemsolving process. The results of the study can be concluded that efforts to improve learning outcomes and critical thinking skills in the material of multiplication and division of class III A SDN 208 / IX Sumber Jaya Academic Year 2019/2020 were pursued using innovative problembased learning to improve student learning outcomes on multiplication and division material. This is shown from the previous student learning outcomes in the initial conditions of 71.92, increasing
\end{abstract}


in cycle I by 77.89 and in cycle II increasing by 90.82. While the KKM achievement obtained by students has increased from the initial conditions of $62.28 \%$, increased in cycle I by $85.18 \%$ with KKM 75 and in cycle II to 82.14\% with KKM 80. Although the percentage increase in KKM achievement has decreased in cycle II, but researchers increased the target and value of KKM in cycle II. Through innovative learning Problem Based Learning can improve students' critical thinking skills in the material of multiplication and division of class III SDN 208 / IX Sumber Jaya Academic Year 2019/2020. The acquisition of student scores can be seen from the critical thinking ability score in the initial conditions of 50.35 with very uncritical criteria increasing in the final condition to 71.62 with the criteria being quite critical.

Key words:

critical thinking; learning outcomes; problem base learning; students

\section{PENDAHULUAN}

Mulai dari tingkat sekolah dasar hingga perguruan tinggi pada setiap jenjang pendidikan matematika merupakan salah satu bidang studi yang harus ada. Matematika merupakan salah satu syarat untuk melanjutkan pendidikan ke jenjang berikutnya, karena dengan matematika, diharapkan siswa dapat berfikir secara kritis, kreatif dan aktif. Pada kelas guru seharusnya mampu memfasilitasi serta menciptakan proses pembelajaran yang baik, yang digemari para siswa dan menyenangkan sehingga dapat mempengaruhi capaian hasil belajar siswa menjadi baik. Model pembelajaran salah satunya adalah dapat menyelesaikan masalah matematika dalam kehidupan sehari-hari, kemudian dapat juga melatih siswa agar dapat berpikir menghadapi masalah matematis dalam kehidupan sehari-hari.

Pembelajaran yang berpusat pada siswa dan menghadapkan siswa pada masalah matematis sehari-hari, merupakan pembelajaran yang ideal, yang mampu membantu siswa untuk belajar matematika dan dapat menyelesaikan masalah secara matematis dan diharapkan pelajaran matematika menjadi digemari siswa untuk dipelajari. Berdasarkan hasil wawancara dan observasi dengan guru kelas III, peneliti mendapatkan informasi bahwa matematika merupakan salah satu mata pelajaran dengan hasil belajar yang rendah pada materi perkalian dan pembagian, dalam mengembangkan kemampuan berpikir kritis siswa untuk menyelesaikan soal cerita maupun soal matematika yang lainnya guru belum maksimal. Ennis dalam (Alec Fisher, 2014), pemikiran yang masuk akal dan reflektif yang berfokus untuk memutuskan apa yang mesti dipercaya atau dilakukan dikatakan berpikir kritis. Dalam konsep Ennis bagian dari berpikir kritis, diharapkan dengan menghadapkan masalah matematis dalam kehidupan sehari-hari kemampuan berpikir kritis siswa meningkat merupakan pengambilan keputusan.

SDN 49/IX Solok memiliki KKM (Kriteria Ketuntasan Minimal) untuk pelajaran matematikan adalah 70 . Berdasarkan batas Kriteria Ketuntasan Minimal maka dapat dilihat siswa yang sudah mencapai KKM sebanyak 18 siswa dan 10 siswa yang belum mencapai KKM. Hasil observasi menyatakan bahwa masih ada 35\% siswa yang belum mencapai KKM untuk materi perkalian dan pembagian. Berdasarkan hasil wawancara dan uraian diatas dapat disimpulkan bahwa hasil belajar matematika kelas III SDN 49/IX Solok rendah pada materi perkalian dan pembagian.

Ukuran untuk mengetahui seberapa jauh seseorang menguasai bahan yang sudah diajarkan merupakan hasil belajar yang sering digunakan. (Purwanto, 2009), Perolehan hasil belajar sering tidak diterima oleh siswa, siswa mengeluh 
dengan tidak puasnya hasil yang mereka peroleh.. Penyebab rendahnya hasil belajar merupakan salah satu faktor yang di sebabkan oleh guru, dimana semestinya pembelajaran pada kelas guru hanya sebagai fasilitator saja dan pembelajaran dipusatkan kepada siswa Karakteristik siswa kelas III dengan masa peralihan dari kelas II, untuk menyelesaikan soal cerita mengubahnya ke dalam bentuk matematika masih mengalami kesulitan.

Pada kenyataannya siswa tidak dilatih untuk berpikir menghadapi masalah matematis dalam kehidupan nyata.Apalagi kemampuan berpikir ini menjadi salah satu bekal utama untuk menyelesaikan soal matematika, termasuk soal cerita. Pembelajaran matematika yang ideal bertujuan untuk menghadapkan siswa dengan realita kehidupan sehari-hari yang memuat permasalahan matematika dan perhitungan matematika.untuk dipikir dan diselesaikan.

Pembelajaran model Problem Based Learning (PBL), yaitu pembelajaran yang menekankan pada masalah kehidupan sehari-hari dan juga merupakan salah satu pembelajaran inovatif yang dapat membantu siswa untuk memahami materi dan meningkatkan kemampuan berpikir kritisnya. Proses belajar mengajar merupakan hasil belajar siswa pada hakikatnya merupakan perubahan tingkah laku setelah melalui proses belajar mengajar.

Karakteristik Problem Based Learning menurut Arends dalam Trianto (2009) adalah sebagai berikut: (1) Pengajuan pertanyaan atau masalah , (2) Pembelajaran berbasis masalah mengorganisasikan pengajaran berdasarkan masalah dan pertanyaan yang terjadi dan masalah tersebut penting untuk dipecahkan dan bermakna bagi seseorang, (3) Berfokus pada keterkaitan antar disiplin. Masalah yang akan dipecahkan adalah masalah yang nyata agar dalam pemecahannya siswa tidak hanya melihat dari satu sisi mata pelajaran tetapi siswa mampu melihat masalah itu dari berbagai mata pelajaran.

Hasil belajar dalam pengertian luas mencakup bidang kognitif, afektif, dan psikomotorik diartikan sebagai tingkah laku. (Majid, 2014). Untuk meningkatkan hasil belajar matematika serta untuk meningkatkan kemampuan berpikir kritis siswa berdasarkan uraian di atas maka perlu dikembangkan suatu pembelajaran inovatif matematika, dengan tujuan mempersiapkan siswa agar menjadi pemecah masalah yang tangguh, pembuat keputusan yang matang dan orang yang tidak pernah berhenti belajar. Hal ini didukung oleh pendapat Susanto (2013), ada dua hal yang mempengaruhi hasil belajar siswa yaitu siswa itu sendiri dan lingkungannya yaitu pertama, kemampuan berpikir atau tingkah laku, bagi siswa serta motivasi, minat, dan kesiapan siswa baik jasmani maupun rohani kemudian yang kedua yaitu sarana dan prasarana, kompetensi guru, kreativitas guru, sumber belajar, metode serta dukungan lingkungan.

Hasil observasi awal terhadap proses pembelajaran matematika di Kelas III SDN 49/IX Solok, dapat diidentifikasikan beberapa masalah sebagai berikut : 1 . masih rendahnya pemahaman siswa tentang konsep perkalian dan pembagian 2. masih kurangnya kemampuan siswa untuk menyelesaikan soal, (3) berpusat pada guru pembelajaran siswa, (4) dalam proses pembelajaran pendekatan yang digunakan oleh guru kurang menarik bagi siswa, sehingga hasil belajar siswa menjadi kurang memuaskan, dan (5) tujuan pembelajaran belum tercapai secara maksimal. Selanjutnya berdasarkan dari identifikasi masalah diatas penelitian ini bertujuan untuk memfokuskan suatu permasalahan yang akan diteliti, dengan pembatasan masalah dalam sebagai berikut: (1) subjek penelitian adalah siswa kelas III SDN 49/IX Solok, semester 
ganjil tahun pelajaran 2019/2020, (2) objek yang diteliti adalah peningkatan hasil belajar matematika dan kemampuan berpikir kritis matematika siswa, (3) model pembelajaran yang digunakan adalah Problem Based Learning (PBL) atau pembelajaran berbasis masalah, dan (4) mata pelajaran yang diteliti adalah matematika dengan materi perkalian dan pembagian.

Berdasarkan uraian latar belakan, identifikasi masalahan, dan pembatasan masalah di atas dapat dirumuskan masalah yang akan dijawab dalam penelitian ini sebagai berikut :

1. Bagaimana penerapan PBL dalam upaya meningkatkan hasil belajar dan kemampuan berpikir kritis siswa kelas III SDN 49/IX Solok tahun ajaran 2019/2020?

2. Apakah penerapan pendekatan Problem Based Learning dapat meningkatkan hasil belajar matematika pada materi perkalian dan pembagian kelas III SDN 49/IX Solok tahun ajaran 2019/2020?

3. Apakah penerapan pendekatan Problem Based Learning dapat meningkatkan kemampuan berpikir kritis matematika pada materi perkalian dan pembagian kelas III SDN 49/IX Solok tahun ajaran 2019/2020?

Tujuan penelitian ini adalah sebagai berikut: (1) mengetahui dan memaparkan bagaimana penerapan PBL untuk meningkatkan hasil belajar dan kemampuan berpikir kritis siswa kelas III SDN 49/IX Solok tahun ajaran 2019/2020, (2) meningkatkan dan mengetahui peningkatan hasil belajar matematika materi operasi hitung perkalian dan pembagian siswa kelas III SDN 49/IX Solok tahun ajaran 2019/ 2016 lewat penggunaan pendekatanProblem Based Learning, dan (3) meningkatkan dan mengetahui peningkatan kemampuan berpikir kritis matematika materi operasi

hitung perkalian dan pembagian siswa kelas III SDN 49/IX Solok tahun ajaran 2019/ 2016 melalui model pendekatan Problem Based Learning.

\section{METODE PENELITIAN}

Penelitian ini ini termasuk Penelitian Tindakan Kelas (PTK). Dalam penelitian ini guru di kelas atau disekolah tempat mengajar yang melakukan penelitian ini, ditujukan pada praktik dan proses pembelajaran serta peningkatan, yang merupakan bagian dari penelitian tindakan kelas (Susilo, 2007). Berbagai model yang dapat digunakan dalam Penelitian Tindakan Kelas. model Kemmis dan Mc. Taggart yaitu Model penelitian yang diadaptasi peneliti dalam penelitian ini.

Model PTK Kemmis dan Mc Taggart terdapat empat langkah untuk setiap siklus yang meliputi: (1) Perencanaan adalah langkah yang dilakukan oleh peneliti ketika akan memulai tindakannya, (2) implementasi dari perencanaan yang sudah dibuat, merupakan pelaksanaan (3) proses mencermati jalannya pelaksanaan tindakan, yaitu pengamatan dan (4) langkah mengingat kembali kegiatan yang sudah lampau yang dilakukan oleh peneliti yaitu refleksi atau dikenal dengan peristiwa perenungan

Tempat penelitian ini dilaksanakan di SDN 49/IX Solok yang terletak di Desa Sumber Jaya Kecamatan Sei Bahar Kabupaten Muaro Jambi. Subjek dalam penelitian ini adalah peserta didik SDN 49/IX Solok tahun pelajaran 2019/2020 kelas III yang berjumlah 21 siswa. Objek penelitian ini adalah peningkatan hasil belajar dan kemampuan berpikir kritis matematika kelas III SDN 49/IX Solok, melalui pembelajaran inovatif Problem Based Learning. Waktu penelitian dilakssiswaan pada semester gasal tahun pelajaran 2019/2020 berkisar pada Juli sampai Nopember 2019.

Teknik pengumpulan data dalam 
penelitian ini menggunakan teknik tes dan non tes yang meliputi: (1) Wawancara, (2) Observasi, dan (3) Tes Untuk Mengukur Hasil Belajar Siswa. Pengumpulan Data Nontes Menggunakan Kuesioner dan Dokumentasi Foto. dalam penelitian ini Instrumen yang digunakan berupa pedoman wawancara, lembar observasi, lembar kuesioner, dan soal tes. Teknik Analisis Data menggunakan teknik analisis kuantitatif dan analisis kualitatif deskriptif. Analisis kuantitatif digunakan untuk hasil tes/evaluasi siswa, menggunakan Analisis kuantitatif sedangkan untuk hasil kuesioner menggunakan analisis kualitatif deskriptif

\section{HASIL DAN PEMBAHASAN Hasil Penelitian}

Peneliti terlebih dahulu melakukan pengamatan dan melihat daftar nilai siswa sebelum memulai penelitian. Hal ini dilakukan untuk melihat kondisi awal yang dimiliki oleh siswa kelas III SDN 49/IX Solok tahun pelajaran 2019/2020. untuk melihat proses belajar mengajar yang dilakukan oleh guru pada saat pembelajaran dilakukan pengamatan dan juga untuk melihat tingkat keterampilan berpikir kritis matematika siswa dilakukan hal yang sama. Daftar nilai diperoleh dari nilai tahun sebelumnya yaitu 2019/2020, nilai ini digunakan untuk mengetahui hasil belajar yang dimiliki siswa khususnya pada materi perkalian dan pembagian. Peneliti juga melakukan kegiatan wawancara dengan guru kelas III untuk mencari informasi tentang karakteristik siswa, proses pembelajaran di kelas, dan kemampuan berpikir kritis matematika siswa.

Siswa di kelas III tergolong siswa yang sangat aktif, , karena empat dari 21 siswa sangat berpengaruh terhadap suasana kelas, karena mereka sangat dominan. masih rendahnya kemampuan berpikir kritis matematika siswa kelas III ditunjukkan pada hasil observasi. Siswa- siswa kurang berminat untuk mengikuti pelajaran matematika, sehingga ketika mereka di kelas banyak melakukan aktivitas lain. Hanya beberapa siswa yang sudah menunjukkan kemampuan berpikir kritis matematika sesuai dengan indikator yang sudah ditentutan peneliti.

Pelaksanaan siklus I dimulai bulan September di kelas III SDN 49/IX Solok tahun pelajaran 2019/2020. Alokasi waktu setiap pertemuan 2 × 35 menit dalam pelaksanaan siklus I dilakukan sebanyak dua kali pertemuan. Mempersiapkan segala sesuatu yang digunakan dan dibutuhkan dalam penelitian ini merupakan perencanaan yang dilakukan oleh peneliti. penyusunan silabus, RPP, LKS, dan soal evaluasi. Selain itu peneliti juga menyusun kuesioner berpikir kritis matematika meliputi bagian dari persiapan. Pada tahap pelaksanaan, kegiatan pembelajaran dilakukan sebanyak dua kali pertemuan dengan alokasi waktu setiap pertemuannya 2 x 32 menit (2jp) menyesuaikan jam pelajaran di SDN 49/IX Solok bahwa setiap jamnya beralokasikan 35 menit. Pertemuan pertama pada siklus I dilakssiswaan pada hari Senin, 21 September 2019 dengan alokasi waktu 2 x 35 menit (2jp). Pertemuan pertama membahas tentang konsep perkalian.

Sebelum

melaksanakan pembelajaran, guru membagikan kuesioner berpikir kritis matematika. Selanjutnya siswa memperhatikan demonstrasi yang dilakukan guru, yaitu menggunakan papan manik-manik. untuk menjelaskan konsep perkalian menggunakan papan manik-manik Guru meminta bantuan kepada seorang siswa. Dengan memberikan pertanyaan kepada siswa : pertanyaan tersebut yaitu : Faisal mempunyai manik-manik 2, kemudian dikalikan 3, jumlah seluruh manik-manik Faisal menjadi berapa? bagaimana cara menghitungnya?. Setelah itu siswa mengerjakan LKS dengan media sedotan, 
yang disusun sesuai dengan contoh demonstrasi guru, setiap kelompok yang terdiri dari 4-5 siswa. Kemudian siswa diminta menyimpulkan pembelajaran pada hari tersebut pada akhir kegiatan.

Pertemuan kedua pada siklus I dilakssiswaan pada hari Selasa, 22 September 2019 dengan alokasi waktu 2 x 35 menit (2jp) sesuai dengan alokasi waktu yang ada di SD N 49/IX Solok. Perkalian satu angka dengan dua angka dibahas pada pertemuan kedua. Kegiatan awal guru melakukan apersepsi. Selanjutnya untuk memancing pengetahuan siswa guru melakukan tanya jawab seputar perkalian. Mendengarkan penjelasan guru tentang perkalian satu angka dengan dua angka, menggunakan papan angka merupakan kegiatan inti siswa Yaitu media yang dibuat dari kertas karton yang diberi tempat- tempat angkaangka dimasukkan, kemudian siswa mencoba mengerjakan LKS dan yang terakhir guru mengadakan sedikit permainan mencongak menggunakan papan angka. Setiap siswa mendapatkan angka-angka, guru akan membacakan soal, dan siapa yang paling cepat akan memasukkan ke dalam papan angka tersebut. Setelah melaksanakan siswa siklus I, peneliti melakukan refleksi terhadap kegiatan yang telah dilakssiswaan. Refleksi yang dilakukan peneliti mencakup dua aspek yaitu yaitu refleksi proses pembelajaran dan refleksi hasil belajar.

Pelaksanaan tindakan pada siklus II dimulai pada kelas III SD N 49/IX Solok Tahun pelajaran 2019/2020. Pelaksanaan siklus II dilakukan Sebanyak dua kali pertemuan, pelaksanaan siklus II dilakukan dengan alokasi waktu di setiap pertemuannya 2 x 35 menit (2jp) sesuai dengan alokasi waktu yang sudah diterapkan di tempat penelitian. Pertemuan pertama pada siklus II dilakssiswaan pada hari Senin, 28 September 2019 dengan alokasi waktu 2 x 35 menit (2jp). Konsep pembagian materi yang dibahas. Pertemuan kedua pada siklus II dilakssiswaan pada hari Selasa, 29 September 2019 dengan alokasi waktu 2 x 35 menit (2jp). Materi yang dibahas adalah pembagian dua bilangan dengan cara bersusun. Kegiatan diawali dengan apersepsi, setelah itu guru memberikan materi. Selanjutnya siswa mengerjakan soal diskusi tentang operasi hitung campuran.

Kegiatan akhir siswa membuat refleksi pembelajaran dan menyimpulkan materi yang telah dipelajari. Sebelum ditutup dengan doa siswa mengerjakan soal evaluasi akhir siklus II secara individu dan mengisi kuesioner kemampuan berpikir kritis matematika.

Selain melakukan kegiatan pembelajaran, peneliti juga melakukan pengamatan. Pengamatan dilakukan observasi dan dengan memberikan kuesioner berpikir kritis kepada siswa setelah proses pembelajaran siklus II selesai. Berdasarkan hasil observasi kemampuan berpikir kritis siswa kelas III, sudah nampak hanya saja masih ada beberapa siswa yang belum menunjukkan kemampuan berpikir kritis sesuai dengan indikator yang sudah ditentukan peneliti. Setelah melakssiswaan siklus II, peneliti melakukan refleksi terhadap kegiatan yang telah dilakssiswaan. Refleksi yang dilakukan peneliti mencakup dua aspek yaitu refleksi proses pembelajaran dan refleksi hasil belajar.

\section{Aspek Peningkatan Hasil Belajar}

Kondisi awal hasil belajar siswa didapatkan dari nilai ulangan siswa kelas III satu tahun sebelumnya pada tahun pelajaran 2019/2020 dengan KKM 70. Hasil belajar siswa kelas III dilihat ratarata, nilai tertinggi, dan nilai terendah. Prosentase siswa tuntas dan presentase siswa tidak tuntas pada tahun 2019/2020 dapat dilihat pada tabel berikut: 
Tabel 1. Data Kondisi Awal Nilai Ulangan Matematika Siswa Kelas III

\begin{tabular}{lc}
\hline \multicolumn{1}{c}{ Keterangan } & Hasil \\
\hline Rata - rata & 71,92 \\
Nilai Tertinggi & 90 \\
Nilai Terendah & 40 \\
Presentase Siswa Tuntas & $64,28 \%$ \\
Presentase Siswa Tidak Tuntas & $35,71 \%$ \\
\hline
\end{tabular}

*) sumber : hasil olah data

Didapatkan nilai rata-rata hasil ulangan matematika Berdasarkan tabel diatas untuk satu tahun terakhir pada materi perkalian dan pembagian diperoleh rata-rata pada tahun 2019/2020 sebesar 71,92 dengan nilai tertinggi 90 dan nilai terendah 40 . Siswa dengan nilai presentase tuntas sebesar 64,28\% dan tidak tuntas persentase siswa sebesar $35,71 \%$. Nilai evaluasi Hasil belajar siswa yang didapatkan dilakukan di akhir siklus I dengan Kriteria Kelulusan Minimal (KKM) 75 dengan mempertimbangkan masukan dari guru kelas Kriteria Kelulusan Minimal (KKM) 75. Data hasil belajar kognitif siswa dapat dilihat pada tabel berikut ini

Tabel 2. Hasil Nilai Evaluasi Siklus I

\begin{tabular}{lc}
\hline Jumlah siswa & 21 \\
Jumlah nilai & 2103 \\
Rata -rata & 77,89 \\
Nilai Tertinggi & 100 \\
Nilai Terendah & 62 \\
Persentase Siswa Tuntas & $85 \%$ (17 siswa) \\
Persentase Siswa Tidak Tuntas & $15 \%$ (3 siswa) \\
\hline
\end{tabular}

*) sumber : hasil olah data

Jumlah siswa berdasarkan tabel diatas sebanyak 21 siswa, tetapi pada saat dilakssiswaan evaluasi akhir siklus I ada seorang siswa yang tidak berangkat, lalu didapatkan jumlah nilai 2103 dengan nilai rata-rata yang diperoleh siswa kelas III materi perkalian dan pembagian adalah sebesar 77,89 dari 21 siswa. Ada 17 siswa dari 20 siswa (85\%) yang mendapatkan nilai di atas KKM .

Kriteria Ketuntasan Minimal (KKM) 80 untuk hasil belajar siswa akhir siklus II, setelah berdiskusi dengan guru kelas peneliti mencoba menaikkan KKM. dapat dilihat data hasil belajar siswa pada tabel berikut ini:

Tabel 3. Hasil Nilai Evaluasi Siklus II

\begin{tabular}{lc}
\hline Jumlah Siswa & 21 \\
Jumlah Nilai & 2543 \\
Rata -rata & 90,82 \\
Nilai Tertinggi & 100 \\
Nilai Terendah & 60 \\
Persentase Siswa Tuntas & $95,23 \%(20$ siswa $)$ \\
Persentase Siswa Tidak Tuntas & $4,76 \%(1$ siswa $)$ \\
\hline
\end{tabular}

*) sumber : hasil olah data

Berdasarkan tabel diatas jumlah siswa terdiri dari 21 orang, dengan jumlah nilai keseluruhan diketahui 2543 dengan nilai rata-rata 90,82. Dikatakan tuntas sebanyak 20 siswa karena dapat mencapai nilai diatas KKM, sehingga dikatakan berhasil pada siklus II dan ke siklus berikutnya tidak dilanjutkan. Data 
persentase hasil belajar dalam bentuk tabel akan disajikan oleh peneliti, dengan menggunakan diagram untuk pencapaian KKM untuk melihat adanya peningkatan agar mempermudah peneliti dari kondisi awal siklus I dan siklus II, sehingga dipaparkan dalam bentuk tabel oleh peneliti seperti berikut:

Tabel 4. Data Hasil Belajar Siswa

\begin{tabular}{ccc}
\hline & \multicolumn{2}{c}{ Rata - rata Nilai } \\
Kondisi awal & Siklus I & Siklus II \\
\hline 71,92 & 77,89 & 90,82 \\
& Persentase Ketuntasan & \\
$64,28 \%$ & $85 \%$ & $95,23 \%$ \\
\hline *) sumber : hasil olah data & &
\end{tabular}

Hasil penelitian menunjukkan bahwa hasil belajar siswa kelas III terjadi peningkatan, hal ini ditunjukkan pada data tabel diatas. Peningkatan hasil belajar siswa diketahui dari kegiatan ujian evaluasi pada setiap akhir siklus I dan siklus II. Indikator ujian evaluasi adalah jumlah perolehan nilai siswa dibandingkan dengan nilai KKM yang telah ditetapkan guru kelas. Dari hasil analisa data nilai ujian evaluasi siswa diketahui terjadi peningkatan nilai rata-rata hasil belajar pada siklus I dan siklus II. Hasil perbandingan nilai ujian pada kondisi awal nilai rata-rata hasil belajar siswa 71,92. Setelah dilakukan penelitian tindakan kelas dengan cara melaksanakan ujian evaluasi pada akhir siklus diperoleh hasil nilai rata-rata yang didapat siswa pada siklus I meningkat 77,89 dari target nilai rata-rata KKM yaitu 75 . Pada siklus II nilai rata-rata ujian evaluasi meningkat menjadi 90,82 dari target nilai rata-rata KKM yaitu 80. Target nilai rata-rata ini ditetapkan berdasarkan masukan dari guru kelas dan mempertimbangkan kondisi hasil belajar siswa. Hasil analisa data menunjukkan bahwa terjadi peningkatan pada setiap siklusnya dari nilai kondisi awal persentase jumlah siswa yang mencapai KKM sebesar 64,28\% sedangkan rata-rata nilai ulangan siswa sebesar 71,92.
Tindakan penelitian siklus I dengan melaksanakan metode pembelajaran PBL, diperoleh nilai rata-rata siswa mengalami peningkatan menjadi 77,89 sebanyak 23 siswa $(82,14 \%)$ dari 28 siswa mencapai target KKM, selebihnya sebanyak 5 siswa (17,86\%) tidak dapat mencapai KKM yang telah ditetapkan. Prestasi hasil belajar pada siklus I boleh dikatakan berhasil, disebabkan nilai yang diperoleh telah melewati kriteria ketuntasan yang ditetapkan peneliti yaitu $70 \%$ dengan nilai KKM 75. Jumlah siswa yang telah mencapai KKM sebesar 85,18\%.

Prestasi pembelajaran ini masih berpotensi untuk dapat ditingkatkan dan dimantapkan, maka penelitian dilanjutkan pada siklus II. Pada siklus II setelah menerapkan pembelajaran PBL perolehan hasil belajar siswa terjadi penurunan, namun demikian nilai KKM meningkat. Pada siklus I nilai KKM ditetapkan sebesar 75 dan ditingkatkan pada siklus II nilai KKM menjadi 80. Perolehan hasil belajar siswa setelah dilaksanakan ujian evaluasi, nilai rata-rata yang diperoleh para siswa sebesar 90,82 nilain ini dicapai oleh sejumlah 23 siswa (82,14\%) dari 28 siswa dari target KKM yang ditetapkan 80 dan sejumlah 5 siswa $(17,86 \%)$ dari 28 siswa belum dapat mencapai nilai KKM.

Berdasarkan hasil refleksi dapat disimpulkan bahwa proses pembelajaran 
pada siklus II dapat berjalan dengan baik dan dapat memenuhi kriteria yang telah ditetapkan dalam penelitian ini. Berdasarkan pencapaian yang telah didapatkan tersebut maka penelitian ini dihentikan sampai siklus II.

\section{Aspek Kemampuan Berpikir Kritis Matematika}

Data keadaan awal keterampilan berpikir kritis matematika siswa diperoleh dari kuesioner yang telah dibagikan kepada siswa sebelum pembelajaran dimulai. Tujuan pembagian kuesioner ini untuk melihat bagaimana kemampuan berpikir kritis siswa terkait mata pelajaran matematika khususnya pada materi perkalian dan pembagian. Indikator Kriteria berpikir kritis ditetapkan sebelumnya berdasarkan tabel dengan Rentang Indikator. Data kondisi awal kemampuan berpikir kritis setiap siswa untuk setiap indikatornya telah diperoleh dari hasil kuesioner, hasil analisa kuesioner diketahui bahwa jumlah siswa yang termasuk dalam kriteria cukup kritis sebanyak 10 siswa dengan persentase 35,71\%.

Berdasarkan tabel kriteria indikator berpikir kritis 1 yaitu mengenal masalah diperoleh jumlah siswa yang termasuk dalam kriteria cukup kritis sebanyak 5 siswa dengan persentase 17,85\%. Selanjutnya berdasarkan tabel kriteria indikator berpikir kritis 2 yaitu menemukan cara-cara yang dapat dipakai untuk menangani masalah diperoleh jumlah siswa yang termasuk dalam kriteria cukup kritis sebanyak 7 siswa dengan persentase $25 \%$. Kemudian dengan dasar kriteria tabel indikator berpikir kritis 4 yaitu menganalisis data diperoleh jumlah siswa yang termasuk dalam kriteria cukup kritis sebanyak 5 siswa dengan persentase $17,85 \%$. Selanjutnya berdasarkan tabel indikator kriteria 5 yaitu menguji kesamaan dan kesimpulan yang diambil individu diperoleh jumlah siswa yang termasuk dalam kriteria cukup kritis sebanyak 17 siswa dengan persentase 60,71\%. Untuk indikator berpikir kritis 6 yaitu membuat penilaian yang tepat tentang hal-hal dan kualitas-kualitas tertentu dalam kehidupan sehari-hari diperoleh jumlah siswa yang termasuk dalam kriteria cukup kritis sebanyak 10 siswa dengan persentase 35,71\%.

Skor yang diperoleh untuk keseluruhan indikator pada kondisi awal diperoleh untuk keseluruhan indikator terdapat seorang siswa dengan kriteria cukup kritis dengan persentase 3,57\% dan nilai rata-rata kelas 50,35 dengan kriteria sangat tidak kritis. Berdasarkan data awal peneliti merangkum skor rata-rata kemampuan berpikir kritis siswa sebagai berikut : (1) nilai kemampuan berpikir kritis untuk indikator mengenal masalah adalah 45 dengan persentase siswa yang minimal cukup kritis 35,71\%, (2) menemukan cara-cara yang dapat dipakai untuk menangani masalah-masalah sebesar 43,8 dengan persentase siswa yang minimal cukup kritis 17,85\%, (3) mengumpulkan dan menyusun informasi yang diperlukan sebesar 56,25 dengan persentase siswa yang minimal cukup kritis 25\%, (4) nilai berpikir kritis menganalisis data 46,16 dengan persentase siswa yang minimal cukup kritis $17,85 \%$, (5) nilai berpikir kritis menguji kesamaankesamaan dan kesimpulan-kesimpulan yang diambil seseorang sebesar 62,5 dengan persentase siswa yang minimal cukup kritis 60,71\% dan (6) nilai berpikir kritis membuat penilaian yang tepat tentang hal-hal dan kualitas-kualitas tertentu dalam kehidupan sehari-hari sebesar 56,6 dengan persentase siswa yang minimal cukup kritis 35,71\%.

Kemampuan berpikir kritis siswa diperoleh dari hasil kuesioner yang telah dibagikan kepada siswa setelah pembelajaran disiklus II selesai. Skor ratarata kondisi akhir untuk setiap indikator sebagai berikut: (1) Skor Rata-Rata 
Indikator 1 Kemampuan Berpikir Kritis Setiap Siswa diperoleh jumlah siswa yang termasuk dalam kriteria cukup kritis sebanyak 12 siswa dengan persentase 42,85\%. (2) Skor Rata-Rata Indikator 2 Kemampuan Berpikir Kritis Setiap Siswa diperoleh jumlah siswa yang termasuk dalam kriteria cukup kritis sebanyak 13 siswa dengan persentase 46,42\%. (3) Skor Rata-Rata Indikator 3 Kemampuan Berpikir Kritis Setiap Siswa diperoleh jumlah siswa yang termasuk dalam kriteria cukup kritis sebanyak 22 siswa dengan persentase 70,57\%. (4) Skor Rata-Rata Indikator 4 Kemampuan Berpikir Kritis Setiap Siswa diperoleh jumlah siswa yang termasuk dalam kriteria cukup kritis sebanyak 19 siswa dengan persentase 67,85\%. (5) Skor Rata-Rata Indikator 5
Kemampuan Berpikir Kritis Setiap Siswa diperoleh jumlah siswa yang termasuk dalam kriteria cukup kritis sebanyak 24 siswa dengan persentase 85,71\%. (6) Skor Rata-Rata Indikator 6 Kemampuan Berpikir Kritis Setiap Siswa diperoleh jumlah siswa yang termasuk dalam kriteria cukup kritis sebanyak 22 siswa dengan persentase $78,57 \%$ dan nilai rata-rata kelas 76,05 dengan kriteria cukup kritis.

Skor yang diperoleh untuk keseluruhan indikator pada kondisi akhir diperoleh jumlah siswa yang termasuk dalam kriteria cukup kritis sebanyak 25 siswa dengan persentase 89,28\%. Berdasarkan uraian diatas peneliti menghitung skor rata-rata dan niai kemampuan berpikir kritis siswa diakhir siklus II:

Tabel 5. Nilai Kondisi Akhir Kemampuan Berpikir Kritis

\begin{tabular}{|c|c|c|c|c|}
\hline No & Indikator & $\begin{array}{l}\text { Skor Rata-rata } \\
\text { Yang Di Capai }\end{array}$ & $\begin{array}{l}\text { Nilai Kemampuan } \\
\text { Berpikir Kritis }\end{array}$ & Persentase \\
\hline 1 & Mengenal masalah & 19,03 & 63,43 & $42,85 \%$ \\
\hline 2 & $\begin{array}{l}\text { Menemukan cara yang dapat } \\
\text { dipakai untukmenangani masalah }\end{array}$ & 19,32 & 64,4 & $46,42 \%$ \\
\hline 3 & $\begin{array}{l}\text { Mengumpulkan dan menyusun } \\
\text { informasi yang diperlukan }\end{array}$ & 16,14 & 80,7 & $70,59 \%$ \\
\hline 4 & Menganalisis data & 21,39 & 71,3 & $67,85 \%$ \\
\hline 5 & $\begin{array}{l}\text { Menguji kesamaan dan kesimpulan } \\
\text { yang diambil seseorang }\end{array}$ & 16,32 & 81,6 & $85,71 \%$ \\
\hline 6 & $\begin{array}{l}\text { Membuat penilain yang tepat } \\
\text { tentang hal-hal dan kualitas- } \\
\text { kualitas tertentu dalam kehidupan } \\
\text { sehari-hari }\end{array}$ & 15,21 & 76,05 & $78,57 \%$ \\
\hline & Keseluruhan & 107,43 & 71,62 & $89,28 \%$ \\
\hline
\end{tabular}

Hasil analisa data nilai kemampuan berikir kritis untuk setiap indikator berpikir kritis yang ditunjukkan pada tabel di atas diperoleh nilai berpikir kritis siswa untuk setiap indikator sebagai berikut : (1) indikator mengenal masalah diperoleh nilai 63,43 dengan persentase siswa minimal cukup kritis 42,85\%, (2) untuk indikator menemukan cara-cara yang dapat dipakai untuk menangani masalahmasalah itu diperoleh nilai 64,4 dengan persentase siswa minimal cukup kritis 46,42\%, (3) indikator mengumpulkan dan menyusun informasi yang diperlukan diperoleh nilai 80,7 dengan persentase siswa minimal cukup kritis 70,59\%, (4) indikator menganalisis data diperoleh nilai 71,3 dengan persentase siswa minimal cukup kritis sebesar 67,85\%, (5) indikator menguji kesamaan-kesamaan dan kesimpulan-kesimpulan yang seorang ambil diperoleh nilai 81,6 dengan persentase siswa minimal cukup kritis sebesar 85,71\% dan (6) indikator membuat penilaian yang tepat tentang halhal dan kealitas-kualitas tertentu dalam 
kehidupan sehari-hari diperoleh nilai 76,05 dengan persentase siswa yang cukup kritis sebesar 78,57\%.

Berdasarkan hasil analisa data penelitian menggambarkan bahwa nilai kemampuan berpikir kritis siswa dalam proses pembelajaran matematika pada seluruh indikator terjadi peningkatan, hal ini diketahui dengan membandingkan dari data kondisi awal dibandingkan kondisi akhir.

\section{Pembahasan}

Penelitian tindakan kelas ini dilakssiswaan dengan tujuan untuk hasil belajar dan kemampuan berpikir kritis matematika pada materi perkalian dan pembagian melalui pembelajaran PBL (Problem Based Learning) siswa kelas III SDN 208/IX Sumber Jaya Tahun Pelajaran 2019/2020.

\section{Proses Penerapan PBL}

Model pembelajaran PBL yang digunakan pada penelitian ini, di mana menekankan masalah pada kehidupan sehari-hari. Dalam proses pembelajaran, peneliti mencoba menerapkan dengan menggunakan media untuk menemukan konsep perkalian dan pembagian yang menstimulus siswa. Untuk menerapkan sintaksis PBL pada setiap pertemuan peneliti mencoba yang meliputi 5 tahap (Arends, 2013) : a) orientasi siswa pada masalah, b) mengorganisasi siswa untuk belajar, c) secara individual maupun kelompok membimbing penyelidikan, d) menyajikan hasil karya dan mengembangkan, serta e) menganalisis dan mengevaluasi proses pemecahan masalah.

Langkah-langkah tersebut dilakssiswaan dalam siklus yang terdiri dari empat kali pertemuan. mampu meningkatkan kemampuan berdasarkan langkah-langkah PBL tersebut sehingga mampu berpikir kritis siswa, karena secara tidak langsung siswa dilatih untuk berpikir dalam menyelesaikan suatu soal dalam kehidupan sehari-hari.

Awalnya peneliti mengalami kesulitan untuk merealisasikan langkahlangkah tersebut di kelas karena kurang berminat terhadap proses pembelajaran dan cenderung ramai di kelas, tetapi dengan sedikit pendekatan dengan ketua kelas, peneliti sangat terbantu untuk mencapai tujuan penelitian.

\section{Hasil Belajar}

Hasil belajar siswa kelas III SDN 208/IX Sumber Jaya tahun 2019/2020 berdasarkan evaluasi yang telah dilakukan pada siklus I dan siklus II mengalami peningkatan khususnya pada materi perkalian dan pembagian. diperoleh dari jumlah rata-rata data hasil belajar siswa hasil evaluasi yang dilakukan disetiap akhir siklus I dan II. Hal ini sejalan dengan pendapat Majid (2014) bahwa hasil belajar dalam pengertian luas, salah satunya mencakup bidang kognitif.

\section{Kemampuan Berpikir Kritis}

Berdasarkan hasil pengamatan yang telah dilakukan pada siklus I dan siklus II maka didapatkan hasil bahwa adanya peningkatan kemampuan berpikir kritis siswa kelas III SDN 208/IX Sumber Jaya tahun pelajaran 2019/2020 ketika mengikuti pembelajaran matematika materi perkalian dan pembagian.

Kemampuan berpikir kritis ini sejalan dengan pendapat Kuswana (2011) berpendapat bahwa berpikir kritis merupakan analisis situasi masalah melalui evaluasi potensi, pemecahan masalah, dan sintesis informasi untuk menentukan keputusan. Diharapkan dengan meningkatnya kemampuan berpikir kritis siswa dapat meningkatkan kemampuan siswa dalam menyelesaikan soal matematika. Sejalan dengan penelitian sebelumnya yang telah dilakukan oleh Susila, Putu Budi, dkk (2014) dengan variabel yang sama dengan 
penelitian ini yaitu tentang berpikir kritis matematika.

Hasil peningkatan kemampuan berpikir kritis dan hasil belajar dapat diketahui dalam penelitian ini, peneliti menjabarkannya dalam bentuk tabel sebagai berikut:

Tabel 6. Perbandingan Pencapaian Penelitian

\begin{tabular}{|c|c|c|c|c|c|c|}
\hline \multirow{2}{*}{ Peubah } & \multirow{2}{*}{ Indikator } & \multirow{2}{*}{$\begin{array}{l}\text { Kondisi } \\
\text { Awal }\end{array}$} & \multicolumn{2}{|c|}{ Siklus I } & \multicolumn{2}{|c|}{ Siklus II } \\
\hline & & & Target & Capaian & Target & Capaian \\
\hline \multirow[t]{2}{*}{ Hasil Belajar } & $\begin{array}{l}\text { Nilai rata-rata } \\
\text { siswa }\end{array}$ & 71,92 & 75 & 77,89 & 80 & 90,82 \\
\hline & $\begin{array}{l}\text { Persentase siswa yang } \\
\text { mencapai KKM }\end{array}$ & $64,28 \%$ & $70 \%$ & $85,18 \%$ & $80 \%$ & $82,14 \%$ \\
\hline \multirow{3}{*}{$\begin{array}{l}\text { Kemampuan } \\
\text { Berpikir Kritis }\end{array}$} & Nilai Kemampuan & \multicolumn{2}{|c|}{ Kondisi Awal } & \multicolumn{3}{|c|}{ Kondisi Akhir } \\
\hline & Berpikir Kritis & \multicolumn{2}{|c|}{$\begin{array}{c}\text { 50,35 } \\
\text { (sangat tidak kritis) }\end{array}$} & \multicolumn{3}{|c|}{$\begin{array}{c}71,62 \\
\text { (cukup kritis) }\end{array}$} \\
\hline & $\begin{array}{l}\text { Persentasekemampuan } \\
\text { Berpikir kritis }\end{array}$ & \multicolumn{2}{|c|}{$3,57 \%$} & \multicolumn{3}{|c|}{$89,28 \%$} \\
\hline
\end{tabular}

Berdasarkan tabel diatas nilai ratarata hasil belajar siswa mengalami peningkatan, hal ini dapat dilihat dari perolehan saat kondisi awal adalah 71,92 meningkat pada siklus I sebesar 77,89 pencapaian 75 sesuai dengan target dan pada siklus II sebesar 90,82 dengan target pencapaian sebesar 80. Selain itu persentase perolehan KKM juga mengalami peningkatan dan telah mencapai target yang ditentukan, hal ini dapat dilihat pada pemerolehan kondisi awal siswa yang mencapai KKM sebesar $64,28 \%$, meningkat pada siklus I sebesar $85,18 \%$ dengan target pencapaian $70 \%$ KKM 75 dan siklus II sebesar 85,71\% dengan target pencapaian 80\% KKM 80.

Sedangkan hasil pengamatan, sebelum proses pembelajaran untuk kemampuan berpikir kritis siswa kuesioner diberikan pada siklus I dan diakhir siklus II. skor pada kondisi awal 2,52 rata-rata (sangat tidak kritis) dan meningkat menjadi 3,58 (cukup kritis).

Dengan demikian, penelitian ini membuktikan bahwa hipotesis tentang penerapan PBL dapat meningkatkan hasil belajar dan kemampuan berpikir kritis siswa materi perkalian dan pembagian siswa kelas III A SDN 208/IX Sumber Jaya tahun pelajaran 2019/2020.

\section{SIMPULAN DAN SAran}

Pada setiap siklus berdasarkan hasil penelitian dapat disimpulkan bahwa :

1. Upaya meningkatkan hasil belajar dan kemampuan berpikir kritis materi perkalian dan pembagian kelas III A SDN 208/IX Sumber Jaya Tahun Pelajaran 2019/2020 ditempuh dengan menggunakan pembelajaran inovatif Problem Based Learning. Adapun langkahlangkah PBL antara lain: 1) mengarahkan siswa kepada masalah, 2) mempersiapkan siswa untuk belajar, 3) membantu penelitiam mandiri dan kelompok, 4) mengembangkan dan menyajikan hasil karya, dan 5) menganalisis dan mengevaluasi proses pemecahan masalah.

2. Melalui pembelajaran inovatif Problem Based Learning dapat meningkatkan hasil belajar siswa pada materi perkalian dan pembagian kelas III A SDN 208/IX Sumber Jaya Tahun Pelajaran 2019/2020. Dari perolehan rata-rata hasil belajar siswa hal ini dapat dilihat sebelumnya pada kondisi awal sebesar 71,92 meningkat pada siklus I sebesar 77,89 dan pada siklus II meningkat lagi sebesar 90,82 . Sedangkan pencapaian KKM yang diperoleh siswa mengalami 
$\pi$ (Phi)

peningkatan dari kondisi awal sebesar 62,28\%, meningkat pada siklus I sebesar 85,18\% dengan KKM 75 dan pada siklus II menjadi 82,14\% dengan KKM 80. Walaupun persentase peningkatan ketercapaian KKM mengalami penurunan pada siklus II, tetapi peneliti meningkatkan target dan nilai KKM disiklus II.

3. Melalui pembelajaran inovatif Problem Based Learning dapat meningkatkan kemampuan berpikir kritis siswa pada materi perkalian dan pembagian kelas III SDN 208/IX Sumber Jaya Tahun Pelajaran 2019/2020. Perolehan nilai siswa dapat dilihat dari nilai kemampuan berpikir kritis kondisi awal 50,35 dengan kriteria sangat tidak kritis meningkat pada kondisi akhir menjadi 71,62 dengan kriteria cukup kritis.

4. Selain itu memperhatikan lagi kondisi awal terlebih dahulu sehingga dalam menentukan target pencapaian tidak terlalu tinggi karena kenyataan di lapangan kadang tidak sesuai dengan yang diharapkan.

\section{DAFTAR PUSTAKA}

Arends, Richard I. (2013). Belajar untuk Mengajar. Jakarta: Salemba Humanika.

Fisher, Alec. (2014). Berpikir Kritis: Sebuah Pengantar. Jakarta: Erlangga

Kuswana. W.S. (2011). Taksonomi Berpikir Perkembangan Ragam Berpikir. Bandung: Remaja Rosdakarya

Majid. (2014). Penilaian Autentik Proses dan Hasil Belajar. Bandung: Rosdakarya

Purwanto. (2009). Evaluasi Hasil Belajar. Surakarta: Pustaka Belajar

Susanto, A. (2013). Teori Belajar
Jurnal Pendidikan Matematika Volume 4 Nomor 2 Tahun 2020

dan Pembelajaran di Sekolah

Dasar. Jakarta: Kencana.

Susila, Putu . Budi. dkk (2014). Pengaruh Pembelajaran Berbasis Masalah Terhadap Kemampuan Berpikir Kritis Siswa Pada Mata Pelajaran Matematika Kelas IV Gugus III Kecamatan Busungbiu. Skripsi. Fakultas Ilmu Pendidikan. Univeristas Pendidika Ganesha.

Susilo. (2007). Panduan Penelitian Tindakan Kelas. Yogyakarta: Pustaka Book Publisher

Trianto.(2009). Mendesain Model Pembelajaran Inovatif Progresif: Konsep, Landasan, dan Implementasinya Pada Kurikulum Tingkat Satuan Pendidikan (KTSP). Jakarta: Kencana. 